\title{
The Uses of Variety
}

THOMAS J. WILSON PRIZE

The Board of Syndics of Harvard University Press has selected this book as co-winner of the thirtieth annual Thomas J. Wilson Prize, honoring the late director of the Press. The Prize is awarded to books chosen by the Syndics as best first books accepted by the Press during the calendar year. 



\section{The Uses of Variety}

Modern Americanism and the Quest for National Distinctiveness

\section{Carrie Tirado Bramen}

\section{HARVARD UNIVERSITY PRESS}

Cambridge, Massachusetts, and London, England 2000 
Copyright (c) 2000 by the President and Fellows of Harvard College

All rights reserved

Printed in the United States of America

Library of Congress Cataloging-in-Publication Data

Bramen, Carrie Tirado, 1964-

The uses of variety : modern Americanism and the quest for national distinctiveness / Carrie Tirado Bramen.

p. cm.

Includes bibliographical references and index.

ISBN 0-674-00308-X (alk. paper)

1. American fiction-History and criticism. 2. Difference (Psychology) in literature. 3. Literature and society-United States-History-20th century. 4. American fiction-Minority authors-History and criticism. 5. United States-Intellectual life-20th century. 6. National characterisctics, American, in literature. 7. Pluralism (Social sciences) in literature. 8. Multiculturalism in literature. 9. Ethnic relations in literature. 10. Minorities in literature. I. Title PS374.D45 B73 2000

813. 009'355-dc21

00-056703 
For David 
